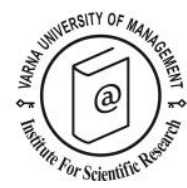

\title{
Correlation between tourists' perceptions/evaluations of destination attributes and their overall satisfactions: Observations of a meta-analysis
}

\author{
Bình Nghiêm-Phú ${ }^{1 *}$
}

Received: 05/10/2017 Accepted: 07/12/2017

1 Department of Business Communication, National Institute of Technology - Fukushima College, 30 Taira Kamiarakawa Nagao, Iwaki, Fukushima 970-8034 Japan. Email: binhnghiem@gmail.com

* Corresponding author

\begin{abstract}
This study examined the correlation between tourists' perception/evaluation of destination attributes and their overall satisfaction. Using the data gathered from 34 previous studies and applying the metaanalysis method, this study found that destination image, destination quality, and destination attribute satisfaction have significant positive effects on the tourists' overall satisfaction, whether the latter variable is singly or multiply scaled; all the overall estimates have small to medium sizes. However, three issues should be taken into account when interpreting this correlation. First, not all of the components of the attribute-based constructs (destination image, destination quality, destination attribute satisfaction) can have significant effects on the overall tourist satisfaction. Second, the unfavourable attributes of a destination may have some negative influences on tourist satisfaction. Third, the attribute-based constructs represent the external/common antecedents of overall tourist satisfactions; their predicting power may be eliminated when controlled by other internal/personal forces, such as personal values. Implications for future research and destination attributes management are discussed based on these observations.
\end{abstract}

(C) 2018 Varna University of Management. All rights reserved

Keywords: destination image, destination quality, destination attribute satisfaction, overall tourist satisfaction, Comprehensive Meta-Analysis (CMA).

Citation: Nghiêm-Phú, B. (2018) Correlation between tourists' perceptions/evaluations of destination attributes and their overall satisfactions: Observations of a meta-analysis. European Journal of Tourism Research 19 pp. 98-115

\section{Introduction}

Within the tourism literature, many individual efforts have been made in examining the linear relationships among destination image, tourist satisfaction and tourist intention (image $\rightarrow$ satisfaction $\rightarrow$ intention to revisit and/or recommend) (Bigné, Sánchez, and Sánchez, 2001; Chen and Tsai, 2007; Chi and Qu, 2008; Jin, Lee, and Lee, 2015; Liu, Li, and Yang, 2015; Park and Njite, 2010; Prayag and Ryan, 2012; Wang and Hsu, 2010). Two syntheses (i.e., meta-analyses) have also been attempted to 
verify the relationship between destination image and tourist intention (Zhang, Fu, Cai, and Lu, 2014), and between satisfaction and tourist intention (Dolnicar, Coltman, and Sharma, 2015). In the former study, Zhang, Fu, Cai, and $\mathrm{Lu}$ (2014) combined the results of 66 papers published between 2000 and 2012 in English and Chinese. The researchers defined five categories of destination image (cognitive, affective, overall, joint cognitive and affective, and self-congruity), and three types of tourist loyalty (attitudinal, behavioural, and composite). Their analysis revealed that almost all the image components had some significant effects on tourist loyalty; joint image, however, did not have a significant influence on attitudinal loyalty. In the latter study, Dolnicar, Coltman, and Sharma (2015) used the database of 25 papers published in Annals of Tourism Research, Journal of Travel Research, and Tourism Management between 2002 and 2011. The outcome of their analysis showed that satisfaction (tourist satisfaction, overall satisfaction, recovery satisfaction, and satisfaction) and intention (behavioural intention, loyalty, word-of-mouth, and intention) had a significant correlation. However, no study has been done to synthesise the correlation between destination image and tourist satisfaction.

Structurally, destination image is a compilation of the cognitive/functional and affective/ psychological attributes that are attached to a destination (Echtner and Ritchie, 2003). Destination attributes, however, also represent the external or pull motivational forces that attract individuals to visit a destination (Yoon and Uysal, 2005), and the experiences and external values that they can have/obtain at the destination (Kim, 2012; Jin, Lee, and Lee, 2015; $\mathrm{Wu}, \mathrm{Li}$, and $\mathrm{Li}, 2014$ ). Additionally, destination attributes are sometimes used as the indicators of destination quality (Chen and Tsai, 2007; Žabkar, Brenčič, and Dmitrović, 2010). These attribute-based constructs, although used in "conceptually different ways" (Dolnicar, Coltman, and Sharma, 2015, p.157), are found to be the significant antecedents of tourist satisfaction (Assaker and Hallak, 2013; Chen, Lee, Chen, and Huang, 2011; Kim, 2012; Yoon and Uysal, 2005).
However, there is no consistency when measuring tourist satisfaction. Many studies gathered tourist evaluation of destination attributes to understand their satisfaction and/or destination performance (Eusébio and Vieira, 2013; Fallon and Schofield, 2004; Kozak and Rimmington, 2000; McDowall and Ma, 2010). Others focused on tourists' overall satisfactions with the destination as a whole (Chen and Tsai, 2007; Kim, Holland, and Han, 2013; Park and Njite, 2010; Tasci and Boylu, 2010). Within the latter group of studies, some used a multipleitem scale while others applied a single-item scale of overall tourist satisfaction. In several attempts, researchers used the measures of satisfaction and intention (Ryan, Shuo, and Huan, 2010), and satisfaction and value for money (Lee, Graefe, and Burns, 2007) to examine the satisfaction construct. In such cases, the construct of tourist satisfaction does not only represent satisfaction.

In summary, there are a great deal of studies examining destination attributes, tourist satisfaction, and the relationship between them. However, the constructs and measures found in previous studies are remarkably diverse. Consequently, although the results seem to be similar and/or identical, no central trend has yet been identified, and error and bias within the existing literature are not eliminated. This study, therefore, collects and categorizes the existing literature on destination attributes (e.g., destination image, destination quality, value, experience, attribute satisfaction) and tourist overall satisfaction to synthesise the understanding of the relationship between them. In order to do so, the meta-analysis method is applied. Generally speaking, meta-analysis "is a set of statistical methods for combining quantitative results from multiple studies to produce an overall summary of empirical knowledge on a given topic" (Littell, Corcoran, and Pillai, 2008, pp. 1-2). As one of its advantages, meta-analysis presents the key findings in a manner that "is more differentiated and sophisticated than conventional review procedures that rely on qualitative summaries or 'vote-counting' on statistical significance" (Lipsey and Wilson, 2001, pp. 1-2).

Following the design of Lau, Ioannidis, and Schmid (1997), this study aims to clarify the 
similarity and dissimilarity in the results of previous studies on the relationship between destination attribute evaluation and tourist overall satisfaction. From there, the study tries to (1) find the overall estimate of this relationship, and (2) explain any dissimilarities that may exist. To achieve these goals, this study begins with a qualitative systematic review of the literature, followed by a calculation of the overall estimates, and concludes with a discussion on the findings and an explanation of the inconsistencies. The structure of the current paper, therefore, will reflect that flow of the research process.

\section{Literature review \\ Destination and destination attributes}

Generally speaking, a destination is the place to which someone or something is going or being sent (Oxford Dictionaries, 2016). In the leisure and tourism contexts, a destination can be as large as a region (Assaker, Vinzi, and O'Connor, 2011), a country (Kim, Agrusa, Chon, and Cho, 2008), a city/province (Kozak and Rimmington, 2000), or as small as a theme park (Wu, Li, and $\mathrm{Li}, 2014$ ), and a festival site (Papadimitriou, 2013). Some smaller places have also been counted as destinations, for example, lodging facilities (Loureiro and Gonzalez, 2008), museums (Gil and Ritchie, 2009), and restaurants (Ryu, Lee, and Kim, 2012). Yet, the latter may be considered as the components of the former. From one perspective, a destination is "a geographical space in which a cluster of tourism resources exist" (Pike, 2008, p.24). In other words, it is an amalgam of tourism products which can offer an integrated experience to tourists (Buhalis, 2000; Fyall, Garrod, and Tosun, 2006). From another perspective, a destination is a place that visitors visit temporarily (Pike, 2008). However, the meaning of a destination is always subjectively perceived and/or interpreted by tourists depending on their travel itinerary, cultural background, purpose of visit, and past experience, among others (Buhalis, 2000).

Each destination in particular and each type of destination in general are attached with a variety of attributes (Baloglu and McCleary, 1999b; Peña, Jamilena, and Molina, 2012; Phillips and Jang, 2010). Those attributes are widely used in the studies on destination image. Specifically, the sensory attributes are the single cognitive images which are perceived through the five senses of human beings. For example, Australia is represented by the visual attributes of kangaroo and the Sydney Opera House, the olfactory attributes of sea and Asian food, the auditory attributes of birds' singing and waves, and the tactile attributes of animals and sand, among others (Son and Pearce, 2005). In the same context, this country is favourably attached to the cognitive attributes of natural attractions and water sports by its international students (Son and Pearce, 2005). The cognitive element can be further divided into three subcategories, including functional or visible attributes (e.g., natural attractions, nightlife and entertainment), psychological or invisible attributes (e.g., hospitality, customs), and mixed functional and psychological attributes (e.g., crowdedness, cleanliness) (Echtner and Ritchie, 2003). These attributes or images are the results of a cognitive mechanism in which individuals process the inputs of information in the form of sensory stimuli to form the aggregated impressions of a destination. Yet, when they use an affective mechanism, or rely on their feelings, to describe or evaluate a destination, the images are the affective ones. Under this approach, any destination can be felt as arousing, exciting, pleasant and relaxing in a sense, and sleepy, gloomy, unpleasant and distressing in another (Russell and Pratt, 1980). When applying the cognitive-affective continuum to conceptualize destination image, other concepts which are labelled differently can also be considered as its special elements, for example, authenticity (Ramkissoon and Uysal, 2011), destination personality (Sahin and Baloglu, 2011), and risk (Fuchs and Reichel, 2011). In addition to the abovementioned specific attributes, a destination may also be described or perceived through its holistic or overall image (Baloglu and McCleary, 1999a; Echtner and Ritchie, 2003), which is the most general and integrative evaluation that individuals have of the destination as a whole.

Moreover, destination attributes are employed in the studies on tourist satisfaction. For example, the four dimensions of British tourists' satisfaction with Mallorca, Spain are "availability 
of English language," "destination attractiveness," "facilities and services at the destination airport," and "tourist attractions and facilities" (Kozak and Rimmington, 2000). The satisfaction of tourists to the central region of Portugal, otherwise, is structured by three components of "accessibility," "attractions," and "basic services" (Eusébio and Vieira, 2013). Destination satisfaction, measured on destination attributes, is equally treated as destination performance in several studies (Fallon and Schofield, 2004; McDowall and Ma, 2010).

Furthermore, some studies use destination attributes as the measures of quality. For example, Chen and Tsai (2007) adopted such attributes as cleanliness, food and beverage, infrastructure, price, safety, and weather to examine tourists' evaluation of trip quality. Similarly, Žabkar, Brenčič, and Dmitrović (2010) developed the construct of "perceived quality of destination's offerings" which includes accessibility, accommodation, attraction, cleanliness, cuisine, people, and safety/security, among others. Furthermore, some researchers also adopted destination attributes in their studies on tourists' external or pull motivations (Yoon and Uysal, 2005), and experiences and external values (Kim, 2012; Jin, Lee, and Lee, 2015; $\mathrm{Wu}, \mathrm{Li}$, and $\mathrm{Li}, 2014)$.

The review of the literature further revealed that several researchers measure only one attribution-based construct in their studies, for example, destination image (Baloglu and McCleary, 1999b), and tourist satisfaction (Yuan, Wu, Zhang, Goh, and Stout, 2007). Some researchers deeply focused on one or two attributes of a destination, for example, safety/ security and hygiene/health (Tasci and Boylu, 2010), and smoke (Li, Pearce, Morrison, and $\mathrm{Wu}, 2016)$. A couple of researchers separate the two basic components of destination image, thus form two different constructs of destination image (i.e., cognitive image), and emotion (i.e., affective image) (Wu and $\mathrm{Ai}, 2016$; Prayag, Hosany, Muskat, and Del Chiappa, 2017). Others use different attributes to measure two distinct concepts, for example, image and experience (Jin, Lee, and Lee, 2015), image and quality (Chen and Tsai, 2007), image and satisfaction (Chi and Qu, 2008), and image and value (Wu, $\mathrm{Li}$, and $\mathrm{Li}, 2014)$. The differences between these practices lay in the coding and/or the scales of the measures. For example, the item of satisfaction with "natural environment" was measured on a terrible/delighted scale in one study (Kozak and Rimmington, 2000), while the item of perception (image, attribute) of "breathtaking scenery and natural attractions" was rated on a disagree/agree scale in another (Chi and Qu, 2008).

\section{Tourist satisfaction}

Within the existing literature, researchers may examine (1) attribute-based satisfaction, (2) overall satisfaction, and (3) both types of satisfaction. Specifically, attribute-based satisfaction is the satisfaction with the various attributes of a destination, and overall satisfaction is the satisfaction with the destination as a whole. Many researchers separately investigate both types of satisfaction in their studies (Correia, Kozak, and Ferradeira, 2013; Fallon and Schofield, 2004; Kozak and Rimmington, 2000; Lee, 2015; Yuan, Wu, Zhang, Goh, and Stout, 2007), while some others combine the measures of attribute-based satisfaction and overall satisfaction (Lee, 2009). When measuring overall satisfaction, researchers may use a single-item scale (Bigné, Sánchez, and Sánchez, 2001; Chen and Tsai, 2007; Park and Njite, 2010), or a multiple-item scale (Kim, Holland, and Han, 2013; Tasci and Boylu, 2010; Tian-Cole, Crompton, and Wilson, 2002; Yoon and Uysal, 2005). In the latter case, the measures vary across studies, which may include overall satisfaction, expectation, delight, enjoyment, worth of time/effort, and wise choice, among others.

\section{Method}

\section{The search of the papers}

This study began with the search of the related literature, which was implemented in January 2016. The tourism, leisure and hospitality management journals listed on SCImago Journal and Country Rank portal (http://www.scimagojr. com/) were used as the base of the search. The portal, in general, includes the journals and country scientific indicators developed from the information kept in the Scopus ${ }^{\circledR}$ database. As of January 2016, the category of tourism, leisure and hospitality management provided the ranking of 78 journals 
in 2014. The Journal of Travel Research was added to the list by the researcher, because this is one of the three leading journals in the field of tourism (Dolnicar, Coltman, and Sharma, 2015). (At the time of the search, Journal of Travel Research was not included in the category of tourism, leisure and hospitality management. However, in the latest ranking of 2017, this journal is number one in this category). This resulted in a list of 79 journals.

The search of the previous studies was conducted as follows. First, the researcher visited the portal of each journal in the list to find related papers. The combination of "destination + image + satisfaction" was used as the single search term across all journals. The researcher read the titles and abstracts of the papers in the search result, and created an initial list of the papers which contain one or more of these keywords in their titles and/or abstracts $(n=$ 135). Among the three keywords, satisfaction served as the milestone one, since it is the dependable variable in the investigated association; there is no such relationship if satisfaction is missing. The other two keywords helped eliminate the studies that did not apply to the context of a destination, and did not examine any attribute-based constructs. Second, the researcher used the databases of two private universities in Eastern Japan (Kanto region) to obtain the papers. Third, the researcher briefly read each paper to see whether it (1) investigated any attribute-based constructs, overall tourist satisfaction, and the relationship between them, and (2) was put into the context of a destination (e.g., a region, a country, a city, a park/forest, a festival site, an industrial site). Those papers $(n=73)$ which satisfied both the abovementioned criteria were kept for further reading and analysis.

Fourth, the researcher reread the remaining papers with an emphasis on the conceptualization and measurement of the attribute-based constructs and overall tourist satisfaction, the analysis of the relationship between them, and the report of the results. After that, an additional 39 papers were eliminated because they (1) had subjectively low reliability (e.g., inconsistency between graphic and textual reports), (2) did not analyse the predictive effect that the attribute-based constructs have on overall tourist satisfaction (but the correlation between them), (3) analysed the predictive effect of overall tourist satisfaction on the attribute-based constructs, (4) did not report the insignificant coefficient(s) of the relationship, (5) reported coefficients whose values exceeded $1.0,(6)$ did not report the measures of overall tourist satisfaction, (7) used the attribute-based measures of both tourist satisfaction and/or other constructs, (8) implemented an incorrect procedure of factor analysis (i.e., to implement factor analysis on the whole sample, then to apply this result to compute regression analysis on the subsamples), and (9) only measured the holistic/overall image of the destination. Regarding the number 4 issue, Zhang, Fu, Cai, and $\mathrm{Lu}(2014)$ replaced the missing values with 0 . However, the insignificant correlations do not necessarily have a value of 0 ; thus, the replacement might reduce/increase the summarized effect. Therefore, this study's researcher chose to exclude from the analysis the research whose insignificant coefficients were missing.

\section{The coding of the data}

The remaining 34 papers (published between 2000 and 2017) were then grouped into nine categories (Table 1) in accordance with the name of the construct (destination image, destination quality, destination attribute satisfaction, destination pull motivation, destination value, and experience), and the type of the measures of overall tourist satisfaction (multiple-item and single-item). The data for the meta-analysis were then collected from each paper and kept in an Excel file. They include the size of the sample, the direct effect that the attribute-based construct had on overall tourist satisfaction, and the direction of the effect (Pierce, 2008). When the model was verified on the whole sample and its subsamples, only the effects observed in the whole sample were recorded. However, when there was no data for the whole sample, the effects observed in each subsample were treated separately; in other words, each analysis on each subsample was considered as an individual study. When there were more than one data point (i.e., the effects 
Table 1. Categorization of the papers

\begin{tabular}{|c|c|c|c|c|c|}
\hline No. & List of papers & $\begin{array}{l}\text { Number } \\
\text { of } \\
\text { papers }\end{array}$ & $\begin{array}{l}\text { Number } \\
\text { of data } \\
\text { points }\end{array}$ & $\begin{array}{l}\text { Attribute- } \\
\text { based } \\
\text { construct }\end{array}$ & $\begin{array}{l}\text { Overall tourist } \\
\text { satisfaction }\end{array}$ \\
\hline 1 & $\begin{array}{l}\text { Anil (2012), Jin, Lee, and Lee (2015), Kim, } \\
\text { Holland, and Han (2013), Li, Pearce, } \\
\text { Morrison, and Wu (2016), Liu, Li, and Kim } \\
\text { (2017), Liu, Li, and Yang (2015), Palau- } \\
\text { Saumell, Forgas-Coll, Amaya-Molinar, and } \\
\text { Sánchez-García (2016), Prayag, Hosany, } \\
\text { Muskat, and Del Chiappa (2017), Song, } \\
\text { Su, and Li (2013), Tasci and Boylu (2010), } \\
\text { Veasna, Wu, and Huang (2013), Wu and } \\
\text { Ai (2016), Wu, Li, and Li (2014) }\end{array}$ & 13 & 13 & $\begin{array}{l}\text { Destination } \\
\text { image }\end{array}$ & Multiple items \\
\hline 2 & $\begin{array}{l}\text { Chen and Tsai (2007), Chi and Qu (2008), } \\
\text { Craggs and Schofield (2011), Park and } \\
\text { Njite (2010), Prayag (2009), Prayag and } \\
\text { Ryan (2012), Tang (2014) }\end{array}$ & 7 & 7 & $\begin{array}{l}\text { Destination } \\
\text { image }\end{array}$ & Single item \\
\hline 3 & $\begin{array}{l}\text { Papadimitriou (2013), Tian-Cole, } \\
\text { Crompton, and Wilson (2002), Žabkar, } \\
\text { Brenčič, and Dmitrović (2010) }\end{array}$ & 3 & 3 & $\begin{array}{l}\text { Destination } \\
\text { quality }\end{array}$ & Multiple items \\
\hline 4 & $\begin{array}{l}\text { Chen and Tsai (2007), Chen, Lee, Chen, } \\
\text { and Huang (2011), Fallon and Schofield } \\
\text { (2004), McDowall and Ma (2010), } \\
\text { Mohamad, Lo, Songan, and Wee (2010) }\end{array}$ & 5 & 5 & $\begin{array}{l}\text { Destination } \\
\text { quality }\end{array}$ & Single item \\
\hline 5 & $\begin{array}{l}\text { Chi and Qu (2008), Correia, Kozak, and } \\
\text { Ferradeira (2013), Eusébio and Vieira } \\
(2013)^{\star}, \text { Kozak and Rimmington (2000), } \\
\text { Lee (2015), Yuan, Wu, Zhang, Goh, and } \\
\text { Stout (2007) }\end{array}$ & 6 & 7 & Satisfaction & Single item \\
\hline 6 & Yoon and Uysal (2005) & 1 & 1 & Pull motivation & Multiple items \\
\hline 7 & Wu, Li, and Li (2014) & 1 & 1 & Value & Multiple items \\
\hline 8 & Jin, Lee, and Lee (2015) & 1 & 1 & Experience & Multiple items \\
\hline 9 & $\operatorname{Kim}(2012)$ & 1 & 1 & Experience & Single item \\
\hline
\end{tabular}

Note. * Paper contributes two data points

of the separate factors), the average value was calculated and used in the analysis.

Since the coding did not involve the interpretation of the latent meanings, the intracoder reliability was sought (Given, 2008). Specifically, the researcher coded and recoded the papers three different times to ensure the accuracy and consistency of the coding. In addition, the researcher also noted the context, the origin of the sample, the label of the construct, and the type and scale of the measures of the attribute-based construct and overall tourist satisfaction (Appendix).

\section{The analysis of the data}

After the necessary data were generated, the analyses were computed in Comprehensive Meta-analysis (CMA) 3.0 (https://www.metaanalysis.com/). CMA was developed by a group of experts from the U.S. and U.K., and is now considered as the world's best-selling product for meta-analysis. This software provides researchers the means (1) to assess the acrossstudy variability in the size of the relationship between a predictor $X$ and a criterion $Y,(2)$ to synthesise the overall estimate of the $X-Y$ relationship, and (3) to examine how the inclusion/removal of a study affects the combined results (Pierce, 2008).

CMA is often compared to STATA, another meta-analysis software, for their formulas and results. Specifically, CMA includes all the same computational formulas used by STATA (see Kan, et al., 2013 for examples of formulas). In addition, the results produced by CMA are identical to those computed by STATA (Bax, Yu, Ikeda, \& Moons, 2007). 
One of the best features of CMA is that it can compute an effect-size estimate in one of more than 100 formats (Pierce, 2008). The examples include the odds ratio and log odds ratio of a dichotomous analysis, the standardized paired difference and raw mean difference of a continuous analysis, and the correlation coefficient and Fisher's $z$ of a correlational analysis, among others. The friendly Window interface of CMA allows researchers to easily copy, cut, and paste their data. When analysing the correlation between two variables, CMA automatically calculates the summarized effect, the $Q$ value (across-study variability or heterogeneity test), and the failsafe number (publication bias test), among others. The outcomes are displayed in traditional tables and high-resolution graphics.

Another excellent feature of CMA is that in can compute a fixed-effect model and a randomeffects model for the core analysis of the correlation between two variables (Pierce, 2008). A fixed-effect model assumes that the effect sizes of previous studies are similar, while a random-effects model assumes the opposite observation. To determine which model's outcome should be reported, researchers may examine the $Q$ values produced by CMA (Hardy \& Thompson, 1998). For example, when the $Q$ value is significant $(p<0.05)$, it is possible to assume that the outcomes of previous studies are heterogeneous; consequently, the randomeffects model can be selected (Dolnicar, Coltman, and Sharma, 2015).

In this study, only five meta-analyses were implemented due to the limited number of papers and data points. The analyses include those of the relationship between destination image and overall tourist satisfaction, between destination quality and overall tourist satisfaction, and between destination attribute satisfaction and overall tourist satisfaction.

\section{Findings and discussions}

\section{Are the results of previous studies similar?}

Obviously, the majority of previous studies found that there is a significantly positive correlation between the attribute-based constructs (i.e., destination image, destination quality /performance, pull motivation, external value, experiences) and overall tourist satisfaction (Bigné, Sánchez, and Sánchez, 2001; Prayag and Ryan, 2012; Wang and Hsu, 2010). However, there are cases when no significant relationship was found (Chen and Tsai, 2007; Kim, Holland, and Han, 2013; Veasna, Wu, and Huang, 2013), or the relationship was significantly negative (Li, Pearce, Morrison, and $\mathrm{Wu}, 2015$; Yoon and Uysal, 2005). In addition, not all the dimensions of the attribute-based constructs could significantly affect tourist satisfaction (Anil, 2012; Lee, 2015; Papadimitriou, 2013). In several recent studies, researchers found that tourist satisfaction could also generate some significant effects on destination image (De Nisco, Mainolfi, Marino, and Napolitano, 2015; Kim, Park, and Kim, 2016), or destination value (Akinci, Kiymalioğlu, and Inana, 2015). However, the theoretical framework of these studies was either missing or scattered.

\section{What are the overall estimates?}

According to the outcomes of the metaanalyses, the $Q$ values were significant $(p<$ $0.05)$. In other words, the effects generated in previous studies were heterogeneous. Consequently, the random-effects models are reported (Table 2).

It was found that the effect that destination image has on the overall tourist satisfaction is positive and significant. However, the effect is larger when the overall satisfaction was measured on a multiple-item scale. Similarly, destination quality was also found to have a significant and positive influence on overall tourist satisfaction, given the type of the measure of overall tourist satisfaction being single- or multiple-item. The effect of the former (destination quality $\rightarrow$ single-item overall tourist satisfaction) is two times smaller than that of the latter (destination quality $\rightarrow$ multiple-item overall tourist satisfaction). Finally, tourists' satisfactions with the attributes of the destination are the positive significant antecedents of their overall satisfactions. The ranges of the summarized effects suggest that the association between the two constructs has a small-tomedium size (Leech, Barrett, and Morgan, 2005). 
Nghiêm-Phú, B. (2018) / European Journal of Tourism Research 19 pp. 98-115

Table 2. The direct effect of the attribute-based constructs on overall tourist satisfaction

\begin{tabular}{|c|c|c|c|c|c|c|c|}
\hline & $\begin{array}{r}\text { Data } \\
\text { points }\end{array}$ & $Q$ value $(p)$ & $\begin{array}{r}\text { Sample } \\
\text { size }\end{array}$ & $\begin{array}{r}\text { Summarized } \\
\text { effect }\end{array}$ & $\begin{array}{l}\text { Summarized } \\
\text { effect range }\end{array}$ & $p$ & $\begin{array}{l}\text { Failsafe } \\
\text { number } \\
\text { (critical } \\
\text { value) }\end{array}$ \\
\hline $\begin{array}{l}\text { Destination image } \rightarrow \\
\text { Overall tourist satisfaction } \\
\text { (multiple-item scale) }\end{array}$ & 13 & $1178.408(0.000)$ & 6679 & 0.506 & $0.487-0.523$ & 0.000 & $5950(75)$ \\
\hline $\begin{array}{l}\text { Destination image } \rightarrow \\
\text { Overall tourist satisfaction } \\
\text { (sinqle-item scale) }\end{array}$ & 7 & $114.885(0.000)$ & 3196 & 0.299 & $0.267-0.330$ & 0.000 & $443(45)$ \\
\hline $\begin{array}{l}\text { Destination quality } \rightarrow \\
\text { Overall tourist satisfaction } \\
\text { (multiple-item scale) }\end{array}$ & 3 & $227.198(0.000)$ & 1790 & 0.634 & $0.606-0.661$ & 0.000 & $549(25)$ \\
\hline $\begin{array}{l}\text { Destination quality } \rightarrow \\
\text { Overall tourist satisfaction } \\
\text { (sinqle -item scale) }\end{array}$ & 5 & $97.348(0.000)$ & 2142 & 0.304 & $0.265-0.342$ & 0.000 & $223(35)$ \\
\hline $\begin{array}{l}\text { Attribute satisfaction } \rightarrow \\
\text { Overall tourist satisfaction } \\
\text { (single -item scale) }\end{array}$ & 7 & $253.102(0.000)$ & 2453 & 0.452 & $0.420-0.483$ & 0.000 & $898(45)$ \\
\hline
\end{tabular}

To check the validity of the analyses, publication bias analyses' results were also examined. It was revealed that the number of excluded or unpublished studies needed to bring the summarized effect down to a statistically insignificant level well exceeded their critical values, which are five times the number of studies plus 10 (Rosenberg, 2005; Zhang, Fu, Cai, and Lu, 2014). This outcome proves that the meta-analyses were reliable.

\section{Why are there dissimilarities in the results of previous studies?}

In the existing literature, there are some studies that reported an insignificant correlation between destination image and overall tourist satisfaction. Chen and Tsai (2007), for example, found that overall tourist satisfaction was only affected by perceived value (time, money, and effort); the importance of destination image (destination brand, entertainment, nature and culture, and sun and sand), and trip quality (hospitality, attractions, transport, and amenity) was insignificant. In another study, Kim, Holland, and Han (2013) discovered that both perceived value (overall and economic), and service quality (product and performance) had some significant effects on overall tourist satisfaction; that of destination image (destination atmosphere, travel information, shopping, and community attitude), however, was insignificant. In Veasna, Wu, and Huang (2013), the authors investigated the influences of destination attachment, destination source credibility, and destination image on overall tourist satisfaction; the only significant antecedent was destination attachment, whose formation was influenced by the other two variables. These findings, however, are not powerful enough to reject the importance of destination image. Otherwise, they suggest that there are other important forces that can control the overall satisfactions of tourists. Specifically, the internal and personal variables (Iso-Ahola, 1982) of destination attachment and perceived value seem to overpower the external variable of destination image when they were combined in the same model (Chen and Tsai, 2007; Veasna, Wu, and Huang, 2013). In addition, the second-level elements of a particular first-level attribute of the destination (e.g., service quality) may have more significant influences on overall satisfactions than the compilation of all the first-level attributes of that destination (e.g., service quality, facilities, attractions, hospitality) (Kim, Holland, and Han, 2013).

Moreover, some studies suggested that the correlation between the attribute-based constructs and overall tourist satisfaction may sometimes have a negative direction. In one case, Li, Pearce, Morrison, and Wu (2016) focused on tourist perception of one unfavourable attribute of the destination (smoke). The negative correlation suggests that the more concerned the tourists were, the less satisfied they could be and vice versa. This interpretation, however, does not contradict the widely ascertained positive association between destination attributes and overall tourist 
satisfaction, which indicates that the more positive the perception of the destination attributes are, the higher the level of satisfaction among tourists is. In another case, Yoon and Uysal (2005) found that the combination of three dimensions of destination image could generate a negative influence on overall tourist satisfaction. However, this dissimilarity can be explained as follows. First, the majority of the components of destination image (modern atmospheres and activities, wide space and activities, natural scenery, restaurants and tennis, different culture, interesting town and village, and water activities) were removed from the analysis. This undertaking has doubtlessly reduced the actual contribution of destination image. Second, the three dimensions included in the model (small size and reliable weather, cleanliness and shopping, and nightlife and local cuisine) may represent the unfavourable facets of the destination as being found in Li, Pearce, Morrison, and Wu (2016). If this is the case, a negative correlation is unavoidable, but is not unexplainable.

Furthermore, the existing literature documents that not all dimensions of the attribute-based constructs can have significant influences on overall tourist satisfaction. For example, in the context of a municipal festival in Kirklareli City (Turkey), "staff", and "informational adequacy" did not generate any significant effects on overall tourist satisfaction (Anil, 2012). In the case of a carnival festival in Patras (Greece), "festival amenities" was the insignificant predictor of overall tourist satisfaction (Papadimitriou, 2013). In another study of the three factory sites in Taiwan (Lee, 2015), the outcomes of regression analyses showed that tourist satisfaction with destination attributes significantly affected their overall satisfaction; yet, among the seven factors of attribute satisfaction, only one (provision of safety and emergency systems) had a significant effect. In summary, the perceptions/evaluations of destination attributes are important with the formation of overall tourist satisfaction. However, some components/attributes may have more contributions than others. The importance of each component/attribute varies across different types of destination (Anil, 2012; Lee, 2015; Papadimitriou, 2013), and probably across different types of tourist (Kim, Holland, and Han, 2013).

\section{Conclusion}

The outcomes of the meta-analyses have confirmed that tourists' perceptions/evaluations (e.g., image, quality, satisfaction) of destination attributes are the significant and positive antecedents of their overall satisfactions. However, three issues should be taken into account when interpreting this correlation. First, not all of the components of the attribute-based constructs can have significant effects on overall tourist satisfaction. Some components are more important than others when contributing to the formation of overall tourist satisfaction. Second, the unfavourable attributes of a destination may have some negative influences on tourist satisfaction. This, nevertheless, does not contradict the overall positive association between tourists' perceptions/ evaluations of destination attributes and their overall satisfactions. Third, the attribute-based constructs represent the external/common antecedents of overall tourist satisfaction. Thus, their predicting power may be eliminated when controlled by other internal/personal forces, such as personal values.

\section{Practical implications}

Destination attributes are multi-dimensionally arranged (cognitive - affective, holistic specific, core - peripheral) (Echtner \& Ritchie, 2003; Lai \& Li, 2012). They are also perceived and evaluated from a variety of perspectives, for example, as the destination images, the quality criteria, and the satisfaction indicators. From any of the abovementioned approaches, perception/evaluation of destination attributes is always an important antecedent of overall tourist satisfaction. Thus, to make tourists satisfied, destination managers should take care of both the beauty (external appearances), and the quality (internal conditions) of their destination's attributes. Interestingly, these two dimensions are inter-correlated (Bouranta, Chitiris, \& Paravantis, 2009; Mugge \& Schoormans, 2012). A fresh and appealing look is the indicator of a good quality, and the good quality helps increase the favourability of an attribute in particular and of a product in general. On the one hand, the external appearances of the 
attributes may be changed to renew and/or diversify the attractiveness of a destination. On the other, the internal conditions of such attributes must be maintained or improved in the long term to guarantee the stability and reliability of products' and services' quality.

However, as suggested by the empirical evidence, not all dimensions/attributes of destination image/quality/satisfaction can affect overall tourist satisfaction. The importance of each dimension/attribute may vary across destinations and tourist types (Anil, 2012; Kim, Holland, and Han, 2013; Lee, 2015; Papadimitriou, 2013). Therefore, a regular investigation of tourists' perceptions/evaluations will help destination managers manage the existing attributes in a more proper and effective manner. As the resources for the maintenance and development of tourist attractions are limited, a regular investigation will help show the destination managers the exact components/attributes that need their attention and focus in a given period.

\section{Theoretical implications}

Meta-analysis is a post-hoc practice which tourism researchers borrow from other fields such as biology (Rosenberg, 2005). While biology researchers can apply an a priori approach to design and operationalize previous studies for a later combined analysis, tourism researchers must rely on what had already been done. Therefore, meta-analysis in tourism is not simply the search for and aggregation of previous studies' results; it requires a careful selection of studies that can be combined to enable a reliable analysis. Meta-analysis, thus, can help reveal the inconsistencies and inaccuracies within previous studies; consequently, it can be a helpful tool for the collection of citable references.

In addition, researchers in tourism should follow what Dolnicar, Coltman, and Sharma (2015) recommended regarding the design and report of their studies. Specifically, all the constructs should be clearly defined and structured, and all the measures of a construct should correspond with its conceptualization. Later on, all the measures and their scales should be reported, together with the coefficient values of all the correlations under investigation. It is a common practice that many researchers did not report the coefficients of the insignificant correlations. This poses difficulties for the post-hoc combination of the findings, and reduces the possibilities of comparison among studies which are put in the same context or employ the similar measures.

\section{Limitations and future directions}

Although this study has made an extensive effort to clean the data and diversify the analysis, it could not avoid some common limits of a metaanalysis. As Zhang, Fu, Cai, and Lu (2014) noted, not all previous studies on the relationship between the attribute-based constructs and overall tourist satisfaction could be collected due to the limited access of databases, and the list of journals. The results of previous studies, which were treated as the data in a meta-analysis, could only be adopted without any cross-checking or cross-validation. External bias or incorrectness (e.g., differences in scales; Dolnicar, Coltman, and Sharma, 2015), if there are any, could not be avoided. Moreover, many contextual characteristics of the previous studies were not considered in the analysis, for example, the other constructs measured in the same model which can affect and alter the actual effect of the correlation between perception/ evaluation of destination attributes and overall tourist satisfaction. Furthermore, since this study was conducted by only one researcher, some internal biases in collecting, cleaning and analysing the results of previous studies may have occurred. However, these processes were implemented and repeated in different times with the inputs of many external comments of meta-analysis and tourism researchers. In addition, the fail-safe numbers (i.e., the results of the publication bias analyses) indicated that only the absence of a very large number of studies (even larger than the initial collection of papers, $n=135$ ) could invalidate the outcomes of these meta-analyses.

Considering the outcomes and limitations of this undertaking, some directions for future study can be proposed as follows. First, it can be realized from the categorization of the studies on destination attributes (Table 1) that the majority defined the issues from the approach of destination image, destination quality, and destination attribute satisfaction research. Thus, there is ample room for researchers to employ 
destination attributes when investigating destination pull motivation and/or value, and experiences at destinations. In addition, more research should be done to address the unfavourable attributes of a destination, which are under-investigated in the existing literature. Second, since a variety of constructs/variables can be measured on destination attributes, it is interesting to combine some of them in the same model, and test the importance of each construct/variable with overall tourist satisfaction, and future tourist behaviours. In the same manner, the comparative significance that the internal/personal (push motivation, personal value), and the external/common (destination attributes) forces can have on overall tourist satisfaction and future tourist behaviours may be retested and confirmed. Third, when simultaneously measuring attribute satisfaction and overall satisfaction, researchers have consistently adopted a single-item scale to capture the latter variable. Thus, future studies may consider developing and using a multipleitem scale of overall satisfaction in this particular line of research. Fourth, it is observed from the two cases of destination image and destination quality (Table 2) that the combined effect when overall satisfaction was measured on a multiplescale is twice as large when it was measured on a single-item scale. Future studies may retest these two scales to further understand their validity and effectiveness.

\section{References}

Akinci, S., Kiymalioğlu, A., and Inana, E. A. (2015). How golf players' satisfaction from golf experience predicts their loyalty intentions? Mediating role of perceived value. International Journal of Culture, Tourism and Hospitality Research, 9(2), 117-132. doi:10.1108/IJCTHR-04-20140033

Anil, N. K. (2012). Festival visitors' satisfaction and loyalty: An example of small, local, and municipality organized festival. Tourism, 60(3), 255-271.

Assaker, G., and Hallak, R. (2013). Moderating effects of tourists' novelty-seeking tendencies on destination image, visitor satisfaction, and short- and long-term revisit intentions. Journal of Travel
Research, 52(5), 600-613. doi:10.1177/ 0047287513478497

Assaker, G., Vinzi, V. E., and O'Connor, P. (2011). Examining the effect of novelty seeking, satisfaction, and destination image on tourists' return pattern: A two factor, non-linear latent growth model. Tourism Management, 32(4), 890-901. doi:10.1016/j.tourman.2010.08.004

Baloglu, S., and McCleary, K. W. (1999a). A model of destination image formation. Annals of Tourism Research, 26(4), 868897. doi: 10.1016/S0160-7383(99)00030-4

Baloglu, S., and McCleary, K. W. (1999b). U.S. international pleasure travelers' images of four Mediterranean destinations: A comparison of visitors and non-visitors. Journal of Travel Research, 38(2), 144152. doi: $10.1177 / 004728759903800207$

Bax, L., Yu, L.-M., Ikeda, N., and Moons, K. G. (2007). A systematic comparison of software dedicated to meta-analysis of causal studies. BMC Medical Research Methodology, 7(40), 1-9. doi:10.1186/ 1471-2288-7-40

Bigné, J. E., Sánchez, M. I., and Sánchez, J. (2001). Tourism image, evaluation variables and after purchase behaviour: Inter-relationship. Tourism Management, 22(6), 607-616. doi:10.1016/S02615177(01)00035-8

Bouranta, N., Chitiris, L., and Paravantis, J. (2009). The relationship between internal and external service quality. International Journal of Contemporary Hospitality Management, 21(3), 275-293. doi:10.1108/ 09596110910948297

Buhalis, D. (2000). Marketing the competitive destination of the future. Tourism Management, 21(1), 97-116. doi:10.1016 /S0261-5177(99)00095-3

Chen, C. M., Lee, H. T., Chen, S. H., and Huang, T. H. (2011). Tourist behavioural intentions in relation to service quality and customer satisfaction in Kinmen National Park, Taiwan. International Journal of Tourism Research, 13(5), 416-432. doi:10.1002/ jtr.810

Chen, C.-F., and Tsai, D. (2007). How destination image and evaluative factors affect behavioral intentions? Tourism 
Management, 28(4), 1115-1122. doi:10.1016/j.tourman.2006.07.007

Chi, C. G.-Q., and Qu, H. (2008). Examining the structural relationships of destination image, tourist satisfaction and destination loyalty: An integrated approach. Tourism Management, 29(4), 624-636. doi:10.1016/ j.tourman.2007.06.007

Correia, A., Kozak, M., and Ferradeira, J. (2013). From tourist motivations to tourist satisfaction. International Journal of Culture, Tourism and Hospitality Research, 7(4), 411-424. doi:10.1108/IJCTHR-052012-0022

Craggs, R., and Schofield, P. (2011). The quays in Salford: An analysis of visitor perceptions, satisfaction and behavioural intention. International Journal of Tourism Research, 13(6), 583-599. doi:10.1002 /jtr.831

De Nisco, A., Mainolfi, G., Marino, V., and Napolitano, M. R. (2015). Tourism satisfaction effect on general country image, destination image, and post-visit intentions. Journal of Vacation Marketing, 21(4), 305-317. doi:10.1177/13567667 15577502

Dolnicar, S., Coltman, T., and Sharma, R. (2015). Do satisfied tourists really intend to come back? Three concerns with empirical studies of the link between satisfaction and behavioral intention. Journal of Travel Research, 54(2), 152-178. doi:10.1177/ 0047287513513167

Echtner, C. M., and Ritchie, J. R. (2003). The meaning and measurement of destination image. The Journal of Tourism Studies, 14(1), 37-48.

Eusébio, C., and Vieira, A. L. (2013). Destination attributes' evaluation, satisfaction and behavioural intentions: A structural modelling approach. International Journal of Tourism Research, 15(1), 66-80. doi:10.1002/jtr.877

Fallon, P., and Schofield, P. (2004). Just trying to keep the customer satisfied. Journal of Quality Assurance in Hospitality and Tourism, 4(3/4), 77-96. doi:10.1300/ J162v04n03 06

Fyall, A., Garrod, B., and Tosun, C. (2006). Destination marketing: A framework for future research. In M. Kozak and L. Andreu (eds.), Progress in tourism marketing (pp. 73-86). Amsterdam: Elsevier.

Fuchs, G., and Reichel, A. (2011). An exploratory inquiry into destination risk perceptions and risk reduction strategies of first time vs. repeat visitors to a highly volatile destination. Tourism Management, 32(2), 266-276. doi:10.1016/j.tourman .2010 .01 .012

Gil, S. M., and Ritchie, J.-R. B. (2009). Understanding the museum image formation process: A comparison of residents and tourists. Journal of Travel Research, 47(4), 480-493. doi:10.1177/ 0047287508326510

Given, L. M. (2008). The SAGE encyclopedia of qualitative methods. Thousand Oaks, CA: SAGE.

Hardy, R. J., and Thompson, S. G. (1998). Detecting and describing heterogeneity in meta-analysis. Statistics in Medicine, 17(8), 841-856. doi:10.1002/(SICI)10970258(19980430)17:8<841::AID-SIM781> 3.0.CO;2-D

Iso-Ahola, S. E. (1982). Toward a social psychological theory of tourism motivation: A rejoinder. Annals of Tourism Research, $9(2), \quad 256-262 . \quad$ doi:10.1016/01607383(82)90049-4

Jin, N., Lee, S., and Lee, H. (2015). The effect of experience quality on perceived value, satisfaction, image and behavioral intention of water park patrons: New versus repeat visitors. International Journal of Tourism Research, 17(1), 82-95. doi:10.1002/jtr.1968

Kan, C., Silva, N., Golden, S. H., Rajala, U., Timonen, M., Stahl, D., and Ismail, K. (2013). A systematic review and metaanalysis of the association between depression and insulin resistance. Diabetes Care, 36(2), 480-489. doi:10.2337/dc12-1442

Kim, S. (2012). The relationships of on-site filmtourism experiences, satisfaction, and behavioral intentions: The case of Asian audience's responses to a Korean historical TV drama. Journal of Travel and Tourism Marketing, 29(5), 472-484. doi:10.1080/10548408.2012.691399

Kim, S. S., Agrusa, J., Chon, K., and Cho, Y. (2008). The effects of Korean pop culture on Hong Kong residents' perceptions of 
Korea as a potential tourist destination. Journal of Travel and Tourism Marketing, 24(2/3), 163-183. doi:10.1080/105484 00802092684

Kim, S.-H., Holland, S., and Han, H.-S. (2013). A structural model for examining how destination image, perceived value, and service quality affect destination loyalty: A case study of Orlando. International Journal of Tourism Research, 15(4), 313328. doi:10.1002/jtr.1877

Kim, S.-K., Park, J.-A., and Kim, W. (2016). The mediating effect of destination image on the relationship between spectator satisfaction and behavioral intentions at an international sporting event. Asia Pacific Journal of Tourism Research, 21(3), 273292. doi:10.1080/10941665.2015.1048262

Kozak, M., and Rimmington, M. (2000). Tourist satisfaction with Mallorca, Spain, as an offseason holiday destination. Journal of Travel Research, 38(3), 260-269. doi:10.1177/004728750003800308

Lai, K., and Li, Y. (2012). Core-periphery structure of destination image: Concept, evidence and implication. Annals of Tourism Research, 39(3), 1359-1379. doi: 10.1016/j.annals.2012.02.008

Lau, J., Ioannidis, J. P., and Schmid, C. H. (1997). Quantitative synthesis in systematic reviews. Annals of Internal Medical, 127(9), 820-826. doi:10.7326/ 0003-4819-127-9-199711010-00008

Lee, C.-F. (2015). Tourist satisfaction with factory tour experience. International Journal of Culture, Tourism and Hospitality Research, 9(3), 261-277. doi:10.1108/ IJCTHR-02-2015-0005

Lee, J., Graefe, A. R., and Burns, R. C. (2007). Examining the antecedents of destination loyalty in a forest setting. Leisure Sciences, 29(5), 463-481. doi:10.1080/01490400 701544634

Lee, T. H. (2009). A structural model to examine how destination image, attitude, and motivation affect the future behavior of tourists. Leisure Sciences, 31(3), 215-236. doi:10.1080/01490400902837787

Leech, N. L., Barrett, K. C., and Morgan, G. A. (2005). SPSS for intermediate statistics: Use and interpretation (2 ed.). Mahwah, $\mathrm{NJ}$ : Lawrence Erlbaum Associates.
Li, J., Pearce, P. L., Morrison, A., and Wu, B. (2016). Up in smoke? The impact of smog on risk perception and satisfaction of international tourists in Beijing. International Journal of Tourism Research, 18(4), 373-386. doi:10.1002/jtr.2055

Lipsey, M. W. and Wilson, D. B. (2001). Practical meta-analysis. Thousand Oaks, CA: SAGE.

Littell, J. H., Corcoran, J., and Pillai, V. (2008). Systematic reviews and meta-analysis. New York, NY: Oxford University Press.

Liu, X., Li, J. J., and Yang, Y. (2015). Travel arrangement as a moderator in imagesatisfaction-behavior relations: An investigation of Chinese outbound travelers. Journal of Vacation Marketing, 21(3), 225-236. doi:10.1177/135676 6714567797

Liu, X., Li, J., and Kim, W. G. (2017). The role of travel experience in the structural relationships among tourists' perceived image, satisfaction, and behavioral intentions. Tourism and Hospitality Research, 17(2), 135-146. doi:10.1177/ 1467358415610371

Loureiro, S. M.-C., and Gonzalez, F. J.-M. (2008). The importance of quality, satisfaction, trust, and image in relation to rural tourist loyalty. Journal of Travel and Tourism Marketing, 25(2), 117-136. doi:10.1080/10548400802402321

McDowall, S., and Ma, E. (2010). An analysis of tourists' evaluation of Bangkok's performance, their satisfaction, and destination loyalty: Comparing international versus domestic Thai tourists. Journal of Quality Assurance in Hospitality and Tourism, 11(4), 260-282. doi:10.1080/ 1528008X.2010.504181

Mohamad, A. A., Lo, M.-C., Songan, P., and Wee, A. Y. (2010). ICTs and tourists' satisfaction. A test on a rural tourist destination. e-Review of Tourism Research, 8(5), 123-135.

Mugge, R., and Schoormans, J. P.-L. (2012). Newer is better! The influence of a novel appearance on the perceived performance quality of products. Journal of Engineering Design, 23(6), 469-484. doi:10.1080/09 544828.2011.618802 
Oxford Dictionaries. (2016). Retrieved February 03, 2016, from http://www.oxforddictiona ries.com/

Palau-Saumell, R., Forgas-Coll, S., AmayaMolinar, C. M., and Sánchez-García, J. (2016). Examining how country image influences destination image in a behavioral intentions model: The cases of Lloret De Mar (Spain) and Cancun (Mexico). Journal of Travel and Tourism Marketing, 33(7), 949-965. doi:10.1080/ 10548408.2015.1075456

Papadimitriou, D. (2013). Service quality components as antecedents of satisfaction and behavioral intentions: The case of a Greek Carnival Festival. Journal of Convention and Event Tourism, 14(1), 4264. doi:10.1080/15470148.2012.755885

Park, Y., and Njite, D. (2010). Relationship between destination image and tourists' future behavior: Observations from Jeju Island, Korea. Asia Pacific Journal of Tourism Research, 15(1), 1-20. doi:10.1080/10941660903510024

Peña, A. I.-P., Jamilena, D. M.-F., and Molina, M. Á.-R. (2012). Validation of cognitive image dimensions for rural tourist destinations: A contribution to the management of rural tourist destinations. Journal of Vacation Marketing, 18(4), 261273. doi:10.1177/1356766712449351

Phillips, W.-M. J., and Jang, S.-C. (2010). Destination image differences between visitors and non-visitors: A case of $\mathrm{New}$ York City. International Journal of Tourism Research, 12(5), 642-645. doi:10.1002/ jtr.776

Pierce, C. A. (2008). Borenstein, M., Hedges, L. V., Higgins, J. P. T, \& Rothstein, H. R. (2006). Comprehensive Meta-Analysis (version 2.2.027) [Computer software]. Englewood, NJ: Biostat. Organizational Research Methods, 11(1), 188-191. doi:10.1177/1094428106296641

Pike, S. (2008). Destination marketing: An integrated marketing communication approach. Amsterdam: Elsevier.

Prayag, G. (2009). Tourists' evaluation of destination image, satisfaction, and future behavioral intentions - The case of Mauritius. Journal of Travel and Tourism Marketing, 26(8), 836-853. doi:10.1080/ 10548400903358729
Prayag, G., and Ryan, C. (2012). Antecedents of tourists' loyalty to Mauritius: The role and influence of destination image, place attachment, personal involvement, and satisfaction. Journal of Travel Research, 51(3), 342-356. doi:10.1177/004728 7511410321

Prayag, G., Hosany, S., Muskat, B., and Del Chiappa, G. (2017). Understanding the relationships between tourists' emotional experiences, perceived overall image, satisfaction, and intention to recommend. Journal of Travel Research, 56(1), 41-54. doi:10.1177/0047287515620567

Ramkissoon, H., and Uysal, M. S. (2011). The effects of perceived authenticity, information search behavior, motivation and destination imagery on cultural behavioral intentions of tourists. Current Issues in Tourism, 14(6), 537-562. doi:10.1080/13683500.2010.493607

Rosenberg, M. S. (2005). The file-drawer problem revisited: A general weighted method for calculating fail-safe numbers in meta-analysis. Evolution, 59(2), 464-468. doi:10.1111/j.0014-3820.2005.tb01004.x

Russell, J. A., and Pratt, G. (1980). A description of the affective quality attributed to environments. Journal of Personality and Social Psychology, 38(2), 311-322.

Ryan, C., Shuo, Y. S., and Huan, T.-C. (2010). Theme parks and a structural equation model of determinants of visitor satisfaction - Janfusan Fancyworld, Taiwan. Journal of Vacation Marketing, 16(3), 185-199. doi:10.1177/1356766710372245

Ryu, K., Lee, H.-R., and Kim, W. G. (2012). The influence of the quality of the physical environment, food, and service on restaurant image, customer perceived value, customer satisfaction, and behavioral intentions. International Journal of Contemporary Hospitality Management, 24(2), 200-223. doi:10.1108/0959611 1211206141

Sahin, S., and Baloglu, S. (2011). Brand personality and destination image of Istanbul. Anatolia: An International Journal of Tourism and Hospitality Research, 22(1), 69-88. doi:10.1080/13032917 .2011 .556222

Son, A., and Pearce, P. (2005). Multi-faceted image assessment: International students' 
views of Australia as a tourist destination. Journal of Travel and Tourism Marketing, 18(4), 21-35. doi:10.1300/J073v18n04 02

Song, Z., Su, X., and Li, L. (2013). The indirect effects of destination image on destination loyalty intention through tourist satisfaction and perceived value: The bootstrap approach. Journal of Travel and Tourism Marketing, 30(4), 386-409. doi:10.1080/ 10548408.2013.784157

Tang, Y. (2014). Travel motivation, destination image and visitor satisfaction of international tourists after the 2008 Wenchuan earthquake: A structural modelling approach. Asia Pacific Journal of Tourism Research, 19(11), 1260-1277. doi:10.1080/10941665.2013.844181

Tasci, A. D., and Boylu, Y. (2010). Cultural comparison of tourists' safety perception in relation to trip satisfaction. International Journal of Tourism Research, 12(2), 179192. doi:10.1002/jtr.745

Tian-Cole, S., Crompton, J. L., and Wilson, V. L. (2002). An empirical investigation of the relationships between service quality, satisfaction and behavioral intentions among visitors to a wildlife refuge. Journal of Leisure Research, 34(1), 1-24.

Veasna, S., Wu, W.-Y., and Huang, C.-H. (2013). The impact of destination source credibility on destination satisfaction: The mediating effects of destination attachment and destination image. Tourism Management, 36, 511-526. doi:10.1016/ j.tourman.2012.09.007

Wang, C.-Y., and Hsu, M. K. (2010). The relationships of destination image, satisfaction, and behavioral intentions: An integrated model. Journal of Travel and Tourism Marketing, 27(8), 829-843. doi:10.1080/10548408.2010.527249

$\mathrm{Wu}, \mathrm{H} .-\mathrm{C}$. , and Ai, C.-H. (2016). A study of festival switching intentions, festival satisfaction, festival image, festival affective impacts, and festival quality. Tourism and Hospitality Research, 16(4), 359-384. doi:10.1177/1467358415610375

Wu, H.-C., Li, M.-Y., and Li, T. (2014). A study of experiential quality, experiential value, experiential satisfaction, theme park image, and revisit intention. Journal of Hospitality and Tourism Research. doi:10.1177/1096348014563396

Yoon, Y., and Uysal, M. (2005). An examination of the effects of motivation and satisfaction on destination loyalty: A structural model. Tourism Management, 26(1), 45-56. doi:10.1016/j.tourman.2003.08.016

Yuan, J., Wu, C., Zhang, J., Goh, B. K., and Stout, B. L. (2007). Chinese tourist satisfaction with Yunnan Province, China. Journal of Hospitality and Leisure Marketing, 16(1/2), 181-202. doi:10.1080/ 10507050802097115

Žabkar, V., Brenčič, M. M., and Dmitrović, T. (2010). Modelling perceived quality, visitor satisfaction and behavioural intentions at the destination level. Tourism Management, 31(4), 537-546. doi:10.1016/ j.tourman.2009.06.005

Zhang, H., Fu, X., Cai, L. A., and Lu, L. (2014). Destination image and tourist loyalty: $A$ meta-analysis. Tourism Management, 40, 213-223. doi:10.1016/j.tourman.2013.06. 006 
Appendix 1. Profiles of the 34 papers

\begin{tabular}{|c|c|c|c|c|c|c|c|c|c|}
\hline Author(s) & Journal & $\begin{array}{l}\text { Type of } \\
\text { destination }\end{array}$ & Context & $\begin{array}{l}\text { Origin of } \\
\text { sample }\end{array}$ & $\begin{array}{l}\text { Label of the } \\
\text { attribute- } \\
\text { based } \\
\text { construct(s) }\end{array}$ & $\begin{array}{l}\text { Type of } \\
\text { attribute } \\
\text { measures }\end{array}$ & $\begin{array}{l}\text { Scale of } \\
\text { attribute } \\
\text { measures }\end{array}$ & $\begin{array}{l}\text { Type of } \\
\text { satisfaction } \\
\text { measures }\end{array}$ & $\begin{array}{l}\text { Scale of } \\
\text { satisfaction } \\
\text { measures }\end{array}$ \\
\hline Anil (2012) & Tourism & Festival site & Turkey & Domestic & Festivalscape & $\mathrm{CA}$ & $\begin{array}{l}5 \text { points, } \\
\text { disagree - agree }\end{array}$ & MS & $\begin{array}{l}5 \text { points, disagree } \\
\text { - agree }\end{array}$ \\
\hline $\begin{array}{l}\text { Chen, Lee, Chen, } \\
\text { and Huang (2011) }\end{array}$ & $\begin{array}{l}\text { International } \\
\text { Journal of Tourism } \\
\text { Research }\end{array}$ & Park & Taiwan & Domestic & Quality & $\mathrm{CA}$ & $\begin{array}{l}5 \text { points, } \\
\text { dissatisfied - } \\
\text { satisfied }\end{array}$ & OS & $\begin{array}{l}5 \text { points, } \\
\text { dissatisfied - } \\
\text { satisfied }\end{array}$ \\
\hline $\begin{array}{l}\text { Chen and Tsai } \\
\text { (2007) }\end{array}$ & $\begin{array}{l}\text { Tourism } \\
\text { Management }\end{array}$ & $\begin{array}{l}\text { Large scale } \\
\text { destination }\end{array}$ & Taiwan & Domestic & $\begin{array}{l}\text { Image } \\
\text { Quality }\end{array}$ & MA & $\begin{array}{l}5 \text { points, } \\
\text { disagree - agree }\end{array}$ & OS & $\begin{array}{l}5 \text { points, disagree } \\
\text { - agree }\end{array}$ \\
\hline Chi and Qu (2008) & $\begin{array}{l}\text { Tourism } \\
\text { Management }\end{array}$ & $\begin{array}{l}\text { Large scale } \\
\text { destination }\end{array}$ & America & $\begin{array}{l}\text { Domestic } \\
\text { International }\end{array}$ & $\begin{array}{l}\text { Image } \\
\text { Satisfaction }\end{array}$ & CA & $\begin{array}{l}7 \text { points, } \\
\text { disagree - agree, } \\
\text { dissatisfied - } \\
\text { satisfied }\end{array}$ & os & $\begin{array}{l}7 \text { points, } \\
\text { dissatisfied - } \\
\text { satisfied }\end{array}$ \\
\hline $\begin{array}{l}\text { Correia, Kozak, } \\
\text { and Ferradeira } \\
(2013)\end{array}$ & $\begin{array}{l}\text { International } \\
\text { Journal of Culture, } \\
\text { Tourism and } \\
\text { Hospitality } \\
\text { Research }\end{array}$ & $\begin{array}{l}\text { Large scale } \\
\text { destination }\end{array}$ & Portugal & International & Satisfaction & $\mathrm{CA}$ & $\begin{array}{l}5 \text { points, worse - } \\
\text { better than } \\
\text { expected }\end{array}$ & OS & $\begin{array}{l}5 \text { points, } \\
\text { dissatisfied - } \\
\text { satisfied }\end{array}$ \\
\hline $\begin{array}{l}\text { Craggs and } \\
\text { Scho?eld (2011) }\end{array}$ & $\begin{array}{l}\text { International } \\
\text { Journal of Tourism } \\
\text { Research }\end{array}$ & $\begin{array}{l}\text { Industrial } \\
\text { site }\end{array}$ & England & $\begin{array}{l}\text { Domestic } \\
\text { International }\end{array}$ & Image & MA & $\begin{array}{l}5 \text { points, } \\
\text { disagree - agree }\end{array}$ & OS & $\begin{array}{l}5 \text { points, } \\
\text { dissatisfied - } \\
\text { satisfied }\end{array}$ \\
\hline $\begin{array}{l}\text { Eusébio and Vieira } \\
\text { (2013) }\end{array}$ & $\begin{array}{l}\text { International } \\
\text { Journal of Tourism } \\
\text { Research }\end{array}$ & $\begin{array}{l}\text { Large scale } \\
\text { destination }\end{array}$ & Portugal & $\begin{array}{l}\text { Domestic } \\
\text { International }\end{array}$ & Satisfaction & $\mathrm{CA}$ & $\begin{array}{l}5 \text { points, bad - } \\
\text { good }\end{array}$ & os & $\begin{array}{l}5 \text { points, } \\
\text { dissatisfied - } \\
\text { satisfied }\end{array}$ \\
\hline $\begin{array}{l}\text { Fallon and } \\
\text { Schofield (2004) }\end{array}$ & $\begin{array}{l}\text { Journal of Quality } \\
\text { Assurance in } \\
\text { Hospitality \& } \\
\text { Tourism }\end{array}$ & $\begin{array}{l}\text { Large scale } \\
\text { destination }\end{array}$ & America & International & Performance & $\mathrm{CA}$ & $\begin{array}{l}7 \text { points, poor - } \\
\text { good }\end{array}$ & os & Not provided \\
\hline $\begin{array}{l}\text { Jin, Lee, and Lee } \\
\text { (2015) }\end{array}$ & $\begin{array}{l}\text { International } \\
\text { Journal of Tourism } \\
\text { Research }\end{array}$ & Park & $\begin{array}{l}\text { South } \\
\text { Korea }\end{array}$ & Domestic & $\begin{array}{l}\text { Image } \\
\text { Experience }\end{array}$ & MA & $\begin{array}{l}7 \text { points, } \\
\text { disagree - agree }\end{array}$ & MS & $\begin{array}{l}7 \text { points, disagree } \\
\text { - agree }\end{array}$ \\
\hline Kim (2012) & $\begin{array}{l}\text { Journal of Travel \& } \\
\text { Tourism Marketing }\end{array}$ & Park & $\begin{array}{l}\text { South } \\
\text { Korea }\end{array}$ & International & Experience & MA & $\begin{array}{l}5 \text { points, } \\
\text { disagree - agree }\end{array}$ & os & Not provided \\
\hline $\begin{array}{l}\text { Kim, Holland, and } \\
\text { Han (2013) }\end{array}$ & $\begin{array}{l}\text { International } \\
\text { Journal of Tourism } \\
\text { Research }\end{array}$ & $\begin{array}{l}\text { Large scale } \\
\text { destination }\end{array}$ & America & $\begin{array}{l}\text { Domestic } \\
\text { International }\end{array}$ & Image & MA & $\begin{array}{l}7 \text { points, } \\
\text { disagree - agree }\end{array}$ & MS & $\begin{array}{l}7 \text { points, disagree } \\
\text { - agree }\end{array}$ \\
\hline $\begin{array}{l}\text { Kozak and } \\
\text { Rimmington (2000) }\end{array}$ & $\begin{array}{l}\text { Journal of Travel } \\
\text { Research }\end{array}$ & $\begin{array}{l}\text { Large scale } \\
\text { destination }\end{array}$ & Spain & International & Satisfaction & CA & $\begin{array}{l}7 \text { points, terrible - } \\
\text { delighted }\end{array}$ & os & $\begin{array}{l}7 \text { points, terrible } \\
\text { - delighted }\end{array}$ \\
\hline
\end{tabular}




$\overrightarrow{\vec{A}} \quad$ Lee (2015)


Li, Pearce,
Morrison, and Wu
(2016)
Liu, Li, and Kim
(2017)

Liu, Li, and Yang
(2015)

McDowall and Ma
(2010)

Mohamad, Lo,
Songan, and Wee
(2010)
Palau-Saumell,
Forgas-Coll,
Amaya-Molinar,
and Sánchez-
García (2016)
Papadimitriou
(2013)

International
Journal of
Culture, Tourism
and Hospitality

Industrial Taiwan Domestic Satisfaction

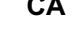

5 points,

dissatisfied -

os

satisfied

5 points,

\section{and Hospitality}

Internationa

site

Smoke

$\begin{array}{ll}\text { International } & \text { Large scale } \\ \text { Journal of Tourism } & \text { destination }\end{array}$

Research

Tourism and

Hospitality

Research

Journal of

Vacation

Marketing

Journal of Quality

Assurance in

Hospitality \&

Tourism

e-Review of

China

International Smoke

Large scale

destination

Large scale

China

Domestic Image

CA

7 points,

disagree - agree

MS

7 points,

disagree - agree

destination

China

Domestic

Image

7 points,

disagree - agree

Large scale Thailand Domestic Performance

Internationa

CA

5 points,

dissatisfied -

satisfied

Quality

Large scale

Malaysia

Domestic

International

Tourism Research destination

Journal of Travel \& Large scale

Spain

Domestic

Image

CA

5 points,

dissatisfied -

satisfied

Tourism Marketing destination

International

5 points,

disagree - agree

MS

MS

MA

Journal of

Festival site

Greece

Domestic

Quality

Convention \&

Event Tourism

Park and Njite

(2010)

Prayag (2009)

Large scale

South

Domestic

Image

Research

Journal of Travel \& $\quad$ Large scale Korea

International Image

Tourism Marketing destination

Prayag, Hosany,

Journal of Travel

Research

Large scale destination

Italy

Domestic

Image

Emotion

Muskat, and De
Chiappa (2017)

\begin{abstract}
Research
\end{abstract}
10 points,

disagree - agree

7 points,

disagree - agree

7 points,

dissatisfied -

satisfied,

unfavorable- -

favorable

7 points,

unfavorable

favorable,

negative -

positive, not at all

- very much dissatisfied -

satisfied

Not provided

7 points

5 points

5 points,

dissatisfied -

satisfied

5 points,

dissatisfied -

satisfied

5 points, disagree

- agree

10 points,

dissatisfied -

satisfied

7 points,

dissatisfied -

satisfied

7 points,

dissatisfied -

satisfied

7 points,

dissatisfied -

satisfied, terrible -

delighted 


\begin{tabular}{|c|c|c|c|c|c|c|c|c|c|}
\hline $\begin{array}{l}\text { Prayag \& Ryan } \\
(2012)\end{array}$ & $\begin{array}{l}\text { Journal of Travel } \\
\text { Research }\end{array}$ & $\begin{array}{l}\text { Large scale } \\
\text { destination }\end{array}$ & $\begin{array}{l}\text { Mauritiu } \\
\text { s }\end{array}$ & Internationa & Image & MA & $\begin{array}{l}7 \text { points, } \\
\text { dissatisfied - } \\
\text { satisfied }\end{array}$ & os & $\begin{array}{l}7 \text { points, } \\
\text { dissatisfied - } \\
\text { satisfied }\end{array}$ \\
\hline $\begin{array}{l}\text { Song, Su, and Li } \\
\text { (2013) }\end{array}$ & $\begin{array}{l}\text { Journal of Travel \& } \\
\text { Tourism Marketing }\end{array}$ & $\begin{array}{l}\text { Large scale } \\
\text { destination }\end{array}$ & China & Domestic & Image & $\begin{array}{l}\text { CA } \\
\text { AA }\end{array}$ & $\begin{array}{l}7 \text { points, } \\
\text { disagree - agree }\end{array}$ & MS & $\begin{array}{l}7 \text { points, disagree } \\
\text { - agree }\end{array}$ \\
\hline Tang (2014) & $\begin{array}{l}\text { Asia Pacific } \\
\text { Journal of Tourism } \\
\text { Research }\end{array}$ & $\begin{array}{l}\text { Large scale } \\
\text { destination }\end{array}$ & China & International & Image & MA & 5 points & OS & $\begin{array}{l}5 \text { points, } \\
\text { dissatisfied - } \\
\text { satisfied }\end{array}$ \\
\hline $\begin{array}{l}\text { Tasci and Boylu } \\
\text { (2010) }\end{array}$ & $\begin{array}{l}\text { International } \\
\text { Journal of Tourism } \\
\text { Research }\end{array}$ & $\begin{array}{l}\text { Large scale } \\
\text { destination }\end{array}$ & Turkey & International & $\begin{array}{l}\text { Safety/security } \\
\text { Hygiene/health }\end{array}$ & CA & $\begin{array}{l}7 \text { points, } \\
\text { dissatisfied - } \\
\text { satisfied }\end{array}$ & MS & $\begin{array}{l}10 \text { points, } \\
\text { dissatisfied - } \\
\text { satisfied }\end{array}$ \\
\hline $\begin{array}{l}\text { Tian-Cole, } \\
\text { Crompton, and } \\
\text { Wilson (2002) }\end{array}$ & $\begin{array}{l}\text { Journal of Leisure } \\
\text { Research }\end{array}$ & Park & America & Domestic & Quality & $\mathrm{CA}$ & $\begin{array}{l}7 \text { points, } \\
\text { disagree - agree }\end{array}$ & MS & $\begin{array}{l}7 \text { points, } \\
\text { unfavorable - } \\
\text { favorable, } \\
\text { dissatisfied - } \\
\text { satisfied, } \\
\text { displeased - } \\
\text { pleased, negative } \\
\text { - positive }\end{array}$ \\
\hline $\begin{array}{l}\text { Veasna, Wu, and } \\
\text { Huang (2013) }\end{array}$ & $\begin{array}{l}\text { Tourism } \\
\text { Management }\end{array}$ & $\begin{array}{l}\text { Large scale } \\
\text { destination }\end{array}$ & $\begin{array}{l}\text { Cambodi } \\
\text { a } \\
\text { Taiwan }\end{array}$ & International & Image & $\mathrm{CA}$ & $\begin{array}{l}7 \text { points, } \\
\text { disagree - agree }\end{array}$ & MS & $\begin{array}{l}7 \text { points, disagree } \\
\text { - agree }\end{array}$ \\
\hline Wu and Ai (2016) & $\begin{array}{l}\text { Tourism and } \\
\text { Hospitality } \\
\text { Research }\end{array}$ & Festival site & China & Domestic & $\begin{array}{l}\text { Image } \\
\text { Emotion }\end{array}$ & $\begin{array}{l}O A \\
A A\end{array}$ & $\begin{array}{l}7 \text { points, } \\
\text { disagree - agree }\end{array}$ & MS & $\begin{array}{l}7 \text { points, disagree } \\
\text { - agree }\end{array}$ \\
\hline $\begin{array}{l}\text { Wu, Li, and Li } \\
(2014)\end{array}$ & $\begin{array}{l}\text { Tourism and } \\
\text { Hospitality } \\
\text { Research }\end{array}$ & Park & Taiwan & Domestic & $\begin{array}{l}\text { Image } \\
\text { Value }\end{array}$ & MA & $\begin{array}{l}7 \text { points, } \\
\text { disagree - agree }\end{array}$ & MS & $\begin{array}{l}7 \text { points, disagree } \\
\text { - agree }\end{array}$ \\
\hline $\begin{array}{l}\text { Yoon and Uysal } \\
\text { (2005) }\end{array}$ & $\begin{array}{l}\text { Tourism } \\
\text { Management }\end{array}$ & $\begin{array}{l}\text { Large scale } \\
\text { destination }\end{array}$ & Cyprus & Domestic & Pull motivation & $\mathrm{CA}$ & $\begin{array}{l}4 \text { points, } \\
\text { unimportant - } \\
\text { important }\end{array}$ & MS & $\begin{array}{l}5 \text { points, worse - } \\
\text { better, not worth - } \\
\text { worth; } 4 \text { points, } \\
\text { dissatisfied - } \\
\text { satisfied }\end{array}$ \\
\hline $\begin{array}{l}\text { Yuan, Wu, Zhang, } \\
\text { Goh, and Stout } \\
(2007)\end{array}$ & $\begin{array}{l}\text { Journal of } \\
\text { Hospitality \& } \\
\text { Leisure Marketing }\end{array}$ & $\begin{array}{l}\text { Large scale } \\
\text { destination }\end{array}$ & China & Domestic & Satisfaction & MA & $\begin{array}{l}5 \text { points, } \\
\text { disagree - agree }\end{array}$ & OS & $\begin{array}{l}5 \text { points, disagree } \\
\text { - agree }\end{array}$ \\
\hline $\begin{array}{l}\text { Žabkar, Brenèiè, } \\
\text { and Dmitroviæ } \\
(2010)\end{array}$ & $\begin{array}{l}\text { Tourism } \\
\text { Management }\end{array}$ & $\begin{array}{l}\text { Large scale } \\
\text { destination }\end{array}$ & Slovenia & $\begin{array}{l}\text { Domestic } \\
\text { International }\end{array}$ & Quality & CA & $\begin{array}{l}5 \text { points, } \\
\text { disagree - agree }\end{array}$ & MS & $\begin{array}{l}5 \text { points, disagree } \\
\text { - agree }\end{array}$ \\
\hline
\end{tabular}

